\title{
PENERAPAN METODE PEMBELAJARAN SOSIODRAMA DALAM MENINGKATKAN MOTIVASI BELAJAR SISWA PADA MATA PELAJARAN IPS KELAS III DI MADRASAH IBTIDAIYAH RAUDHLATUSSYBYAN NW BELENCONG KECAMATAN GUNUNGSARI
}

\author{
Saprun \\ Program Studi PGMI, Universitas Muhammadiyah Mataram, Indonesia \\ Ssaprun95@gmai.com
}

\begin{tabular}{l} 
INFO ARTIKEL \\
Riwayat Artikel: \\
Diterima: 05-03-2020 \\
Disetujui: 30-04-2020 \\
\hline
\end{tabular}

Kata Kunci:

Penerapan Metode, Pembelajaran Sosiodrama, Meningkatkan Motivasi Belajar Siswa.

\section{Keywords:}

Method Implementation, Sociodrama Learning, Increasing student learning motivation.

\section{A. LATAR BELAKANG}

Pendidikan adalah usaha sadar dan terencana untuk mewujudkan suasana belajar dan proses pembelajaran agar peserta didik secara aktif mengembangkan potensi dirinya untuk memiliki kekuatan spiritual keagamaan, pengendalian diri, kepribadian, kecerdasan, dan akhlak mulia, serta keterampilan yang diperlukan dirinya, masyarakat, bangsa dan negara. ${ }^{1}$ Pendidikan merupakan salah satu hal yang sangat penting dan mendasar bagi kehidupan manusia, karena sudah menjadi kebutuhan setiap orang untuk memajukan peradaban dalam mengembangkan generasi. Menurut Undangundang Sisdiknas No. 20 Tahun 2003 yang

${ }^{1}$ System Pendidikan Nasional Nomor 20 Tahun 2003, ( Bandung: Fokus Media,2003). hlm 38 
menyatakan bahwa pendidikan berperan mengembangkan kemampuan dan membentuk watak serta peradaban bangsa yang bermartabat dalam rangka mencerdaskan kehidupan bangsa, mengembangkan potensi anak agar menjadi manusia yang beriman dan bertakwa kepada Tuhan Yang Maha Esa, berakhlak mulia, sehat, berilmu, cakap, mandiri, kreatif, dan menjadi warga Negara yang Demokratis dan bertanggung jawab. ${ }^{2}$ Jadi tugas seorang guru memang berat, sebab kemajuan suatu bangsa ditentukan oleh keberhasilan pendidikan dari bangsa itu sendiri. Pendidikan dapat diartikan sebagai proses dimana tingkah laku di ubah melalui latihan atau pengalaman. Oleh karena itu, pendidikan sangat perlu untuk dikembangkan dari berbagai ilmu pengetahuan,karna pendidikan yang berkualitas dapat meningkatkan kecerdasan suatu bangsa. Peningkatan kualitas pendidikan tentunya berkaitan erat dengan siswa, guru, sistem pendidikan, metode yang di gunakan, orang tua dan lingkungan. Masalah yang dihadapi dalam dunia pendidikan adalah masalah lemahnya proses pembelajaran. Dalam proses pembelajaran siswa kurang didorong untuk mengembangkan keterampilan berpikir. Proses pembelajaran di dalam kelas diarahkan kepada kemampuan siswa untuk menghafal informasi, siswa terbiasa untuk mengingat dan menimbun informasi, tanpa berusaha untuk menghubungkan yang diingat itu dengan kehidupan sehari-hari. Akibatnya siswa hanya pintar secara teoritis tetapi miskin dalam aplikasi.Untuk mencapai tujuan belajar mengajar, maka salah satu usaha yang dilakukan oleh seorang guru adalah dengan memilih atau menggunakan berbagai metode pembelajaran yang tepat dalam proses pembelajaran, seperti menggunakan metode Sosiodrama, ceramah, tanyajawab, serta kesiapan guru dalam menyampaikan materi pembelajaran, dan kesiapan dari para peserta didik itu sendiri untuk menerima materi pembelajaran.

Metode adalah cara atau prosedur yang keberhasilannya adalah didalam belajar, atau sebagai alat yang menjadikan mengajar menjadi efektif. ${ }^{3}$ Sebab metode mengajar dapat menentukan berhasil atau tidaknya kegiatan didalam proses belajar mengajar, oleh karena itu dalam penelitian ini peneliti mengambil metode Sosio drama yang nantinya akan bisa menumbuhkan motivasi siswa dalam pembelajaran IPS. Sosiodrama berasal dari kata

${ }^{2}$ Ahmad Susanto. Pengembangan Pembelajaran IPS di SD (Jakarta:Kencana.2014).,1

${ }^{3}$ Abdul Azis Wahab,Metode dan Model-model Mengajar IPS (Bandung: Alfabeta, 2009). 36-37 sosio dan drama. Sosio berarti sosio menunjuk pada obyeknya yaitu masyarakat menunjukkan padake giatan-kegiatan sosial, dan drama berarti mempertunjukkan, mempertontonkan atau memperlihatkan. Sosial atau masyarakat terdiri dari manusia yang satu sama lain terjalin hubungan yang dikatakan hubungan sosial. Metode sosio drama berarti cara menyajikan bahan pelajaran dengan mempertunjukkan dan mempertontonkan atau mendramatisasikan cara tingkah laku dalam hubungan sosial. ${ }^{4}$

Jadi sosio drama adalah metode mengajar yang mendramatisasikan suatu situasi sosial yang mengandung suatu problem, agar peserta didik dapat memecahkan suatu masalah yang muncul dari suatu situasi sosial. Dengan penerpan metode sosio drama pembelajaran yang tepat dan efektif siswa akan lebih termotivasi untuk lebih giat lagi dalam meningkatkan belajarnya, sehingga hasil belajar atau prestasi yang dicapai diharapkan lebih meningkat. Sejalan dengan itu Rusdiana menyatakan "motivasi dipahami sebagai keadaan dalam diri individu yang menyebabkan seseorang berprilaku dengan cara yang menjamin tercapainya suatu tujuan". ${ }^{5}$ Jadi dapat dipahami bahwa motivasi dapat diartikan sebagai keseluruhan daya penggerak dalam diri seseorang untuk melakukan serangkaian kegiatan guna mencapai tujuan yang diinginkan.

Berdasarkan hasil observasi penelitin menemukan rendahnya daya serap belajar, minat belajar, serta sulitnya siswa dalam memahami materi pembelajaran IPS dikarenakan Pembelajaran IPS di MI Raudlatusshibyan NW Belencong, guru sering menggunakan metode pembelajaran ceramah, dimana siswa mendengarkan guru yang memberikan penjelasan tentang materi pembelajaran. ${ }^{6}$ Akan tetapi, model pembelajaran ini tidak dapat membangkitkan aktifitas siswa dalam belajar karena siswa pasif mendengarkan dan bertanya sekali-sekali, sehingga membuat peserta didik merasa bosan dan sulit memahami apa yang telah guru sampaikan. Dengan di terapkannya metode sosiodrama dalam proses belajar mengajar, peneliti berasumsi bahwa seorang guru IPS bisa menumbuhkan motivasi untuk para siswa dalam pembelajaran.

Namun berhasilnya proses belajar mengajar IPS juga tidak terlepas dari kesiapan para peserta didik dan kesiapan guru. Oleh karena itu individu yang ingin mempelajari IPS senantiasa aktif dalam

${ }^{4}$ Turkiran Taniredja, Model-model pembelajaran Inovatif dan efektif (Bandung:Alfabeta.2015).,39-40

${ }^{5}$ Rusdiana, kewirausahaan Teori dan Praktik,(Bandung:Pustaka setia,2014).,69

${ }^{6}$ Observasi. Jumat, 4 mei 2018 di kelas III MI Raudlatusshibyan NW belencong. 
pembelajaran sehingga tercapainya hasil belajar yang tinggi sesuai apa peserta didik dan guru harapkan. Berdasarkan uraian pada masalah diatas peneliti mengangkat penelitian dengan judul: Penerapan Metode Pembelajaran Sosiodrama Dalam Meningkatkan Motivasi Belajar Siswa Pada Mata Pelajaran Ips Kelas Iii Di Madrasah Ibtidaiyah Raudhlatussybyan NW Belencong Kecamatan Gunungsari Tahun Ajaran 2017/2018.

\section{B. METODE PENELITIAN}

Rancangan penelitian yang digunakan oleh peneliti yaitu Penelitian Tindakan Kelas (PTK). PTK adalah penelitian yang dilakukan oleh guru di dalam kelasnya sendiri melalui refleksi diri, dengan tujuan untuk memperbaiki kinerjanya sebagai guru, sehingga hasil belajar siswa menjadi meningkat. ${ }^{7}$ Maka dalam penelitian ini perlu adanya kerjasama antara pihak-pihak yang terlibat yaitu guru, kepala sekolah, dan siswa berdasarkan kondisi dan situasi kelas dalam pelaksanaan pembelajaran mata pelajaran ilmu pengetahuan sosial kelas III demi tercapainya indikator yang sudah di susun sebelumnya. Dalam penelitian tindakan kelas ini, guru dijadikan sebagai peneliti dan penanggung jawab penuh. Guru dalam hal ini peneliti, terlihat secara penuh dalam perencanaan, tindakan, observasi, dan refleksi pada tiap-tiap siklusnya. Penelitian tindakan kelas ini dilaksanakan dalam 2 siklus.

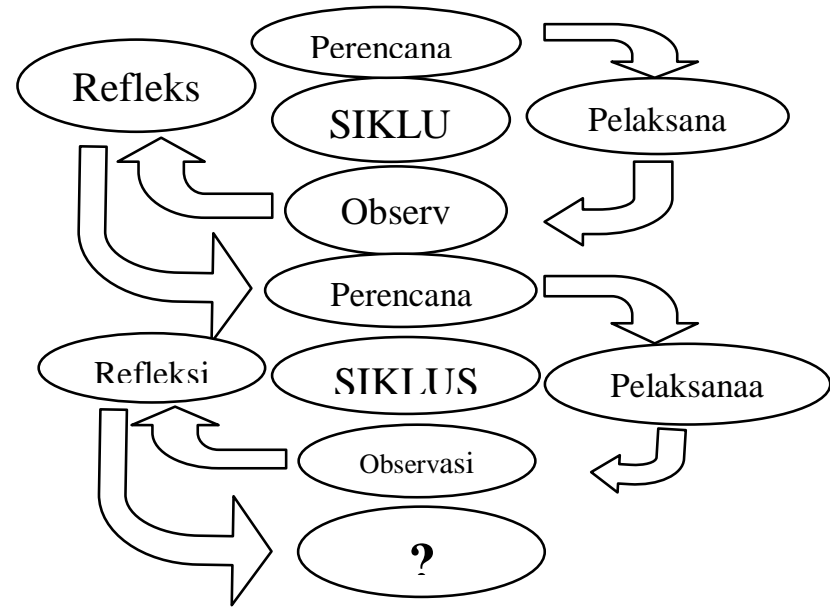

Gambar 1. Tahapan dalam Penelitian Tindakan Kelas $^{8}$

\section{Lokasi penelitian}

Lokasi penelitian adalah tempat dimanapenelitian akan dilakukan, beserta jalan dan kotanya. Dalam penelitian ini peneliti mengambil lokasi di Madrasah Ibtidaiyyah

${ }^{7}$ Igak Wardhani, Penelitian Tindakan Kelas modul 1, (Jakarta: Universitas Terbuka, 2008).,4

${ }^{8}$ Suharsimi Arikunto. Penelitian Tindakan Kelas ( Jakar: Bumi Aksara,2006).,16
Raudlatusshibyan NW Belencong, terletak di Jl. Raya Tanjung Belencong Desa Midang Kecamatan Gunungsari Kabupaten Lombok Barat Propinsi Nusa Tenggara Barat.

\section{Instrumen Penelitian dan Teknik Pengumpulan Data}

Menurut Sumarno, Alat pengumpul data dapat disederhanakan, baik penyusunannya maupun cara pemakainya. Alat tersebut dapat menghasilkan data yang jelas, bermakna, dan dapat dimanfaatkan dengan mudah. Alat pengumpulan data dapat berupa wawancara, observasi dan dokumentasi. ${ }^{9}$

Maka teknik pengumpulan data yang relevan dalam penelitian ini adalah:

1) Wawancara

Wawancara adalah metode pengambilan data yang dilakukan dengan cara menanyakan kepada responden secara langsung dan bertatap muka tentang beberapa hal yang diperlukan dari suatu fukos penelitian. ${ }^{10}$ Wawancara dapat berupa: tidak terencana misalnya obrolan informal diantara pelaku penelitian atau antara pelaku penelitian dengan subjek penelitian. Terencana tetapi tidak terstruktur: satu atau dua pertanyaan pembukaan dari pewawancara, tetapi setelah itu pewawancara memberikan kesempatan bagi responden untuk memilih topik yang akan dibicarakan. Terstruktur: pewawancara telah menyusun rangkaian pertanyaan yang akan diajukan dan akan mengendalikan percakapan sesuai dengan arah pertanyaan. ${ }^{11}$ Diantara ketiga bentuk tes wawancara yang telah dipaparkan, peneliti akan menggunakan tes wawancara terstruktur.

2) Observasi

Secara bahasa, observasi adalah mengamati. ${ }^{22}$ Sementara di sisi lain, observasi penelitian bukan hanya memenuhi rasa ingin tahu, tapi bagaimana suatu fenomena yang diketahui tersebut menjadi pengetahuan. Namun suatu pengetahuan selalu membawa konsekuensi pertanggungjawaban, baik moral, intelektual maupun sosial. Oleh karena itulah, observasi dalam penelitian tidak hanya sekedar melihat atau mengamati, namun dilakukan secara lebih konprehensif, detail, dengan tujuan yang jelas, dan sebagian dilakukan dengan menggunakan indikator, parameter dan tersistem dengan jelas. ${ }^{13}$ Observasi yang digunakan adalah observasi

${ }^{9}$ Medi Yanto, Penelitian ...., hlm. 64

${ }^{10}$ Abd Rahman A. Ghani, Metodologi Penelitian Tindakan Sekolah, (Jakarta: Rajawali Pers, 2016), hlm. 176

${ }^{11}$ Medi Yanto, Penelitian....hlm.64,

${ }^{12}$ Abd Rahman A. Ghani, Metodologi..., hlm. 143

${ }^{13}$ Ibid, hlm. 145 
langsung, ketika pembelajaran berlangsung yang dilaksanakan pada siswa kelas III di MI Raudlatusshibyan NW Belencong, terhadap motivasi belajar siswa, aktivitas belajar siswa dan aktivitas mengajar guru melalui penggunaan media sosiodrama pada mata pelajaran IPS.

\section{3) Dokumentasi}

Metode dokumentasi merupakan tehnik pengumpulan data penelitian mengenai hal-hal atau variabel yang berupa catatan, transkrip, buku, surat, majalah, prasasti, notulen rapat, leger nilai, agenda dan lain-lain. ${ }^{14}$ Penelitian mengaplikasikan tentang keaktifan siswa, daftar hadir siswa dan hasil belajar siswa selama mengikuti pembelajaran IPS yang dilakukan pada siswa kelas III di MI Raudlatusshibyan NW Belencong Tahun Pelajaran 2017/2018.

\section{Teknik pengumpulan data}

Teknik analisis data dalam PTK, langkahlangkah yang dilakukan dalam analisis data penelitian yaitu:

\section{a. Teknik observasi}

Objek yang akan diteliti atau diobservasi merupakan data yang sangat penting dalam penggunaan penerapan media sosiodrama adalah siswa kelas III MI Raudlatusshibyan NW Belencong. Observasi yang dilakukan adalah:

1) Minat siswa terhadap mata pelajaran IPS

2) Keaktifan dalam belajar.

3) Menjawab pertanyaan.

4) Mengerjakan tugas yang diberikan oleh guru.

5) Memberikan pendapat. ${ }^{15}$

b. Teknik tes

Untuk memperoleh data yang akan di analisis diperlukan alat atau instrumen pengumpulan data yang lain, selain observasi yang dilakukan, untuk itu peneliti mengadakan pengetesan. Pengetesan dilakukan pada saat peneliti mengadakan pembelajaran IPS di kelas IV MI Raudlatusshibyan NW Belencong. Tes dapat berupa pilihan ganda, isian atau sesuai dengan kondisi yang dilakukan dalam pembelajaran yang sedang dilakukan.

\section{c. Penarikan Kesimpulan}

Tujuan akhir dari setiap penelitian adalah mendapatkan kesimpulan mengenai hal-hal apa yang telah disampaikan dengan penelitian yang telah dilakukan. Kesimpulan merupakan hasil tertinggi dalam suatu penelitian, dengan

\footnotetext{
hlm. 97

${ }^{14}$ Johni Dimyati, Metodologi Penelitian, (Jakarta: Kencana, 2013),

${ }^{15}$ Igak Wardhani, penelitian tindakan kelas modul 2 (jakarta: universitas terbuka,2008).,31
}

diperolehnya kesimpulan, maka masalah yang disajikan, dibahas dan dicarikan solusinya akan nampak dengan jelas. Maka kesimpulan merupakan penjabaran yang tersusus secara sistematika dari seluruh rangkaian kegiatan penelitian.

\section{Teknik Analisis Data}

1. Teknik analisis kualitatif

Pada penelitian tindakan kelas ini peneliti menggunakan analisis deskripsi kualitatif. Analisis deskripsi kualitatif yaitu suatu metode yang bersifat menggambarkan kenyataan atau fakta sesuai dengan data yang diperoleh dengan tujuan untuk mengetahui hasil belajar yang dicapai siswa dan untuk mengetahui respon siswa terhadap kegiatan pembelajaran serta aktifitas siswa selama proses pembelajaran berlangsung. Analisis ini dihitung dengan menggunakan statistik sederhana berikut ini:

\section{Penilaian Tugas dan Tes}

Peneliti menjumlahkan nilai yang diperoleh siswa, selanjutnya dibagi dengan jumlah siswa kelas tersebut sehingga diperoleh nilai rata-rata dengan menggunakan rumus:

$$
x \frac{\Sigma X}{\Sigma N}
$$

Keterangan $\mathrm{x}$ : nilai rata-rata kelas

$\Sigma X$ : jumlah semua nilai siswa

$\Sigma \mathrm{N}$ : jumlah siswa

\section{a. Penilaian untuk ketuntasan belajar}

Ada dua kategori ketuntasan belajar, yaitu secara perorangan dan secara klasikal. ${ }^{16}$ Berdasarkan petunjuk pelaksanaan pembelajaran, peneliti menganggap bahwa penggunaan media sosio drama pada mata pelajaran IPS dengan pertanyaan terstruktur ini dikatakan berhasil dalam meningkatkan hasil belajar siswa jika siswa mampu menyelesaikan soal dan memenuhi nilai ketuntasan. Ketuntasan individual jika siswa memperoleh nilai 80 kategori nilai kognitif siswa tampak pada tabel berikut:

\section{Tabel 2 kategori nilai kognitif siswa ${ }^{17}$}

\begin{tabular}{|l|l|}
\hline Rentang Nilai & Kategori \\
\hline$\geq 85$ & Sangat Tinggi \\
\hline $70-84$ & Tinggi \\
\hline $55-69$ & Sedang \\
\hline $40-54$ & Rendah \\
\hline$\leq 30$ & Sangat Rendah \\
\hline
\end{tabular}

Nilai kognitif yang diperoleh siswa kemudian

\footnotetext{
${ }^{16} \mathrm{Ibid}$, hlm. 40

${ }^{17}$ Zainal Aqib, Penelitian Tindakan Kelas (PTK) Untuk Guru $S D, S L B, T K$ (Bandung: CV Yrama Widya, 2010), hlm. 41
} 
disesuaikan dengan tabel ketuntasan untuk mengetahui tuntas atau tidak tuntasnya siswa pada aspek kognitif ini, berikut tabel ketuntasan nilai kognitif siswa.

\begin{tabular}{|l|l|l|}
\hline No & Nilai & Kategori \\
\hline 1 & $\geq 75$ & Tuntas \\
\hline 2 & $\leq 75$ & Tidak Tuntas \\
\hline
\end{tabular}

\section{Tabel 3 Kategori Nilai Ketuntasan Siswa}

Untuk menghitung persentase ketuntasan belajar, digunakan rumus sebagai berikut:

\section{$\mathrm{p}=\frac{\Sigma \text { siswa yang tuntas belajar }}{\Sigma \text { siswa }} \times 100 \%$}

Analisis ini dilakukan pada saat tahapan refleksi. Hasil analisis ini digunakan sebagai bahan refleksi untuk melakukan perencanaan lanjut dalam siklus selanjutnya. ${ }^{18}$

\section{b. Kinerja guru}

Data kinerja guru diperoleh dari pengamatan langsung ketika melaksanakan pembelajaran di kels. Nilai kinerja guru dihitung menggunakan rumus:

$$
N K=\frac{R}{S M} \times 100
$$

Keterangan: $\mathrm{NK}=$ nilai kinerja guru

$$
\begin{aligned}
& \mathrm{R}=\text { jumlah skor yang diperoleh } \\
& \mathrm{SM}=\text { skor maksimum } \\
& 100=\text { bilangan tetap }^{19}
\end{aligned}
$$

Selanjutnya nilai kinerja guru dikonversi ke dalam kategori berikut.

\begin{tabular}{|l|l|}
\hline Rentang Nilai & Kategori \\
\hline$\geq 85$ & Sangat baik \\
\hline $76-84$ & Baik \\
\hline $55-75$ & Cukup baik \\
\hline$\leq 54$ & Kurang baik \\
\hline
\end{tabular}

Tabel 4 Kategori kinerja guru berdasarkan perolehan nilai. ${ }^{20}$

\section{Teknik Analisis Kuantitatif}

Analisis kuantitatif digunakan untuk menganalisis hasil belajar pengetahuan atau aspek kognitif siswa dalam hubungannya dengan penguasaan materi yang dibelajarkan. Analisis data ini bertujuan untuk mengetahui tingkat ketuntasan belajar siswa yang diperoleh dari tiap siklus.

\footnotetext{
${ }^{18}$ Medi Yanto, Penelitian...,hlm 41

${ }^{19}$ Zainal Aqib, Penelitian..., hlm. 141

${ }^{20}$ Ngalim Purwanto, Prinsip-Prinsip dan Teknik Evaluasi Pengajaran, (Bandung: Remaja Rosdakarya, 2008), hlm.78
}

a. Nilai kognitif individual siswa diperoleh melalui rumus:

$$
N p=\frac{R}{S M} \times 100
$$

Keterangan :

$$
\begin{array}{ll}
\mathrm{Np} & =\text { Nilai yang dicari } \\
\mathrm{R} & =\text { Jumlah nilai yang diperoleh } \\
\mathrm{SM} & =\text { Nilai maksimum } \\
100 & =\text { Bilangan tetap } 21
\end{array}
$$

Ketentuan individual jika siswa memperoleh nilai 75 kategori nilai kognitif siswa tampak pada tabel berikut:

Tabel 5 kategori nilai kognitif siswa

\begin{tabular}{|l|l|}
\hline Rentang Nilai & Kategori \\
\hline$\geq 85$ & Sangat Tinggi \\
\hline $75-84$ & Tinggi \\
\hline $55-70$ & Sedang \\
\hline $40-54$ & Rendah \\
\hline$\leq 30$ & Rendah \\
\hline
\end{tabular}

Nilai kognitif yang diperoleh siswa kemudian disesuaikan dengan tabel ketuntasan untuk mengetahui tuntas atau tidak tuntasnya siswa pada aspek kognitif ini berikut tabel ketuntasan nilai kognitif siswa.

Tabel 6 kategori nilai ketuntasan siswa

\begin{tabular}{|l|l|l|}
\hline No & Nilai & Kategori \\
\hline 1 & $\geq 75$ & Tuntas \\
\hline 2 & $\leq 75$ & Tidak Tuntas \\
\hline
\end{tabular}

Sumber: KKM MI Raudlatusshibyan NW Belencong

b. Nilai rata-rata siswa yang diperoleh melalui rumus:

$$
\overline{\mathrm{X}}=\frac{\sum x}{\sum N}
$$

Keterangan:

$$
\begin{aligned}
\overline{\mathrm{X}} & =\text { Nilai Rata-Rata } \\
\sum X & =\text { Jumlah Semua Nilai Siswa } \\
\sum N & =\text { Jumlah Siswa }^{22}
\end{aligned}
$$

c. Presentasi ketuntasan hasil belajar kognitif secara klasikal

Presentasi ketentuan belajar klasikal siswa dapat diperoleh dengan menggunakan rumus sebagai berikut:

$$
\mathrm{P}=\frac{\sum \text { siswa yang tuntas }}{\sum \text { siswa }} \times 100 \%
$$

keterangan :

\footnotetext{
${ }^{21}$ Ibid, $1 \mathrm{hm} .102$

${ }^{22}$ Zainal Aqib, Penelitian Tindakan Kelas (PTK) Untuk Guru SD, SLB,TK (Bandung: CV Yrama Widya, 2010), hlm. 40
} 
$\mathrm{P} \quad=$ persentase ketuntasan secara klasikal

$\Sigma \quad=$ menyatakan jumlah siswa

$100 \%$ = bilangan tetap. ${ }^{23}$

\section{HASIL DAN PEMBAHASAN}

Penerapan Metode Pembelajaran Sosiodrama Dalam Meningkatkan Motivasi Belajar Siswa Pada Mata Pelajaran IPS Kelas III di Madrasah Ibtidaiyah NW Belencong Kecamatan Gunungsari Kabupaten Lombok Barat.

Penelitian tindakan kelas ini dilakukan untuk meningkatkan motivasi belajar siswa pada materi pokok jual beli pada siswa kelas III semester 2 di Madrasah Ibtidaiyah Raudlatusshibyan NW Belencong. Jumlah siswa kelas III adalah 15 orang siswa. Dari hasil observasi dan evaluasi diperoleh data kualitatif berupa aktivitas siswa dan aktivitas guru yang memberikan gambaran tentang kegiatan siswa dan guru selama proses belajar mengajar, serta data kuantitatif yaitu data hasil evaluasi pada akhir kegiatan pembelajaran yang memberikan gambaran ketuntasan belajar siswa secara klasikal yang diperoleh melalui tes yang dilakukan pada akhir setiap siklus.

Adapun hasil penelitian dalam setiap siklus adalah sebagai berikut:

\section{Siklus I}

Pada siklus I peneliti melaksanakan kegiatan belajar mengajar dalam 1 kali pertemuan. Pada tanggal 21 Juli 2018 dengan alokasi waktu $3 \times 35$ menit dan evaluasi dilaksanakan pada Hari yang sama. Materi yang dipelajari pada siklus I adalah memahami jual beli. Kegiatan pada siklus I terdiri dari 4 tahap antara lain:

a. Tahap Perencanaan

Hal-hal yang telah dilakukan peneliti dan guru pada tahap perencanaan sebagai berikut

1. Peneliti berkomunikasi terlebih dahulu mengenai tahap perencanan yang akan dilaksanakan pada tahap pelaksanaan tindakan, seperti RPP, media dan sebagainya.

2. Guru dan peneliti menetapkan pokok bahasan tentang " jual beli ".

3. Peneliti membuat RPP dengan motode pembelajaran Sosiodrama, sebelumnya peneliti sudah berkomunikasi terlebih dahulu mengenai RPP dengan metode pembelajaran Sosiodrama dengan guru kelas selaku pengampu mata pelajaran IPS.

4. Peneliti mempersiapkan lembar kerja siswa/LKS yang berupa soal pilihan ganda. Peneliti juga mempersiapakan lembar observasi aktivitas guru dan siswa selama proses pembelajaran yang telah dibuat.

5. Peneliti juga mempersiapkan alat mengajar yaitu gambar, spidol dan buku.

b. Tahap Pelaksanaan Tindakan

Pada tahap ini, RPP siklus I diterapkan serta dilakukan pengamatan sesuai dengan lembar observasi yang telah dipersiapkan. Secara garis besar tahap pelaksanaan tindakan ditinjau dari penerapan motode pembelajaran sosiodrama pada siklus I dapat diuraikan sebagai berikut:

\section{Siklus I}

\section{Kegiatan Awal}

Pada kegiatan awal siklus I guru membuat skenario pembelajaran guru juga menyiapkan alat dan bahan untuk mengajar, serta menjelaskan dengan rinci langkah-langkah motode pembelajaran Sosiodrama dalam mengerjakan soal LKS. Guru membuka interaksi awal dengan memberikan apersepsi menyampaikan kembali beberapa konsep penting yang belum dikuasai siswa mengenai materi jual beli " anak-anak siapa yang tahu apa itu Jual Beli? Terlihat diawal pembelajaran siswa masih sibuk sendiri dan masih mengerjakan pekerjaan lain atau tidak fokus terhadap pembelajaran.

2. Kegiatan Inti

Pada kegiatan inti guru menjelaskan materi yang dipelajari yaitu menjelaskan pengertian Jual Beli dan meminta siswa untuk membuka Buku paket, setelah itu Guru meminta satu persatu dari siswa untuk membaca materi yang sedang di pelajari. Kemudian guru melakukan tanya jawab dan menunjukkan beberapa siswa untuk menjawab pertanyaan dari guru mengenai pembelajaran yang sedang di pelajari " siapa yang tahu pengertian jual beli?", dan beberapa siswa masih tampak malu untuk mengajukan pertanyaan-pertanyaan yang belum jelas dan memberikan pendapatnya. Guru selanjutnya membagikan LKS.

Setelah semua siswa selesai mengerjakan LKS, guru menugaskan siswa untuk membahas hasil diskusinya di depan kelas. Guru membimbing siswa saat membaca hasil diskusi di depan kelas,

3. Kegiatan Akhir

Pada akhir pembelajaran siklus I, guru hanya melaksanakan beberapa kegiatan akhir yang dapat dilaksanakan guru hanya mentutup pelajaran dengan membaca hamdalah dikarenakan alokasi waktu yang disediakan tidak cukup. Kegiatan yang paling banyak menghabiskan waktu yaitu pada kegiatan inti, dikarenakan pada saat kegiatan inti siswa masih senang main dalam menjawab soal, siswa juaga malu untuk maju di depan kelas saat kegiatan Evaluasi . Hal ini disebabkan karena guru 
kurang menguasai situasi kelas saat pembelajaran berlangsung.

c. Tahap Observasi dan Evaluasi

1. Hasil observasi aktivitas mengajar guru

Pada proses pembelajaran di kelas, guru melakukan aktivitas mengajar sesuai dengan rencana pelaksanaan pembelajaran siklus I. Aktivitas guru selama proses pembelajaran berlangsung diamati oleh observer yaitu guru kelas III. Hasil observasi terhadap aktivitas guru dalam pembelajaran yang terdiri dari beberapa poin atau indikator yang di nilai oleh observer yaitu:

a) Perencananan dan persiapan penyelenggaraan pembelajaran yang terdiri dari tiga poin guru hanya melaksanakan atau yang terlihat tampak ada dua poin yang terlaksana

b) Pemberian motivasi apersepsi kepada siswa hanya satu yang tampak atau terlaksana.

c) Aktivitas guru dalam membimbing siswa ketika mengerjakan LKS atau diskusi, guru terlihat tampak dan membimbing siswa selama mengerjakan LKS/diskusi

d) Kemampuan guru dalam menciptakan kelas yang kondusif, guru melakukan tepuk tangan ketika melihat siswa yang tidak memperhatikan selama guru menjelaskan materi yang dipelajari

e) Pendampingan siswa dalam diskusi kelompok guru tidak hanya memperhatikan keseriusan siswa selama diskusi tetapi guru bergiliran mendatangi kelompok-kelompok lain dan memberikan arahan tiap-tiap kelompok yang mengalami kesuitan dalam mengerjakan LKS.

f) Pemberian umpan balik terhadap hasil diskusi, guru tidak melakukan tanya jawab dengan siswa hanya saja guru meminta kepada siswa untuk menyampaikan hasil diskusinya di depan kelas.

Berdasarkan lembar observasi aktivitas guru siklus I terlihat bahwa aktivitas guru berkategori cukup baik, hal ini sesuai dengan pedoman kriteria aktivitas guru berdasarkan interval. Adapun kekurangan pada kegiatan pembelajaran siklus I diantaranya:

a) Guru tidak mengecek kehadiran siswa.

b) Guru tidak menyampaikan tujuan pembelajaran.

c) Guru tidak mengaitkan materi pelajaran yang akan dibahas dengan materi sebelumnya atau dengan kehidupan nyata.

d) Guru tidak membuat menarik perhatian siswa agar lebih konsentrasi dalam pembelajaran.

e) Guru tidak memberi komentar dan saran terhadap hasil diskusi siswa. f) Guru tidak melakukan tanya jawab dengan siswa untuk menarik kesimpulan dari materi yang telah dipelajari.

2. Hasil observasi aktivitas belajar siswa

Data aktivitas siswa selama kegiatan pembelajaran berlangsung diperoleh dengan menggunakan lembar observasi. Aktivitas belajar siswa yang dilakukan oleh observer, terdiri dari beberapa indikator atau poin yang harus ditempuh oleh siswa agar siswa dikatakan aktif selama proses pembelajaran berlangsung yaitu:

a) Penggunaan metode pembelajaran Sosiodram,siswa terlihat sangat tampak mampu mempertanggungjawabkan hasil LKS yang mereka kerjakan.

b) Antausias siswa dalam mengikuti kegiatan pembelajaran, siswa masih ada yang mengerjakan pekerjaan yang lain selama proses pembelajaran berlangsung, sebagian dari siswa yang tetap memperhatikan pelajaran dengan seksama selama proses pembelajaran dan tidak terpengaruh dengan situasi kelas selama pembelajaran berlangsung.

Berdasarkan lembar observasi aktivitas siswa siklus I terlihat bahwa aktivitas siswa berkategori cukup aktif, hal ini sesuai dengan pedoman kriteria aktivitas siswa berdasarkan interval. Dari hasil observasi aktivitas siswa siklus I terdapat beberapa kekurangan dalam proses pembelajaran, diantaranya:

a) Hanya terdapat beberapa siswa yang menjawab pertanyaan guru mengenai materi sebelumnya yang berkaitan dengan materi yang akan diajarkan.

b) Siswa belum berani untuk mengajukan pertanyaan/mengemukakan pendapatnya pada guru.

c) Siswa masih ragu-ragu dalam mengajukan pertanyaan/menanggapi pertanyaan yang diajukan kelompok lain.

d) Siswa masih mengerjakan pekerjaan lain selama pembelajaran berlangsung

e) Kurangnya partisipasi siswa dalam memberikan kesimpulan terhadap materi yang telah diberikan.

f) Siswa belum tertib dan tenang saat melakukan diskusi ketika menyajikan hasil diskusinya di depan kelas.

3. Hasil evaluasi siswa

Guru melakukan evaluasi untuk melihat sejauh mana siswa menyerap materi yang sudah diajarkan di kelas. Evaluasi siklus I dilaksanakan pada pertemuan selanjutnya pada tanggal 22 Juni 2018 dengan memberikan soal dalam bentuk pilihan ganda. Hasil yang dicapai pada evaluasi siklus I adalah nampak siswa yang mengikuti tes 
14 orang, dengan nilai tertinggi 90 dan nilai terendah 50. Sedangkan jumlah tes evaluasi yaitu 10 dan nilai rata-rata siswa yaitu 76,4. Presentase ketuntasan klasikal yaitu $64 \%$ dengan jumlah siswa yang tuntas sebanyak 9 orang dan jumlah siswa yang tidak tuntas sebanyak 5 orang. Dari lima orang siswa yang tidak tuntas 1 siswa 50, 3 siswa 70 dan 1 siswa nilainya 65, dilihat dari siswa yang tidak tuntas tersebut disebabkan karena kurang memperhatikan penjelasan yang disampaikan oleh guru selama proses pembelajaran berlangsung. Guru juga kurang interaktif dalam penyampaian materi pembelajaran yang membuat minat belajar siswa menurun.

\section{d. Tahap Refleksi}

Dilihat dari ketuntasan secara klasikal, aktivitas belajar siswa, dan kekurangankekurangan yang terjadi pada kegiatan pembelajaran siklus I, ternyata belum memenuhi kriteria/indikator ketercapaian secara keseluruhan. Maka dari itu penelitian ini dilanjutkan ke siklus II, dengan terlebih dahulu melakukan perbaikan terhadap kekurangankekurangan pada siklus I. Adapun hal-hal yang sudah terlaksana pada siklus I yaitu:

1. Guru mengajukan pertanyaan untuk menggali kemampuan awal siswa.

2. Guru menyampaikan materi pembelajaran secara jelas dan melibatkan siswa secara langsung dalam kegiatan pembelajaran.

3. Guru membimbing siswa dalam pengisian LKS, baik secara individu maupun kelompok.

4. Guru memberikan kesempatan kepada siswa untuk menyajikan hasil diskusi di depan kelas.

Adapun yang belum dilaksanakan pada pembelajaran siklus I, antara lain:

1. Guru tidak menyampaikan manfaat mempelajari materi yang dibahas kepada siswa.

2. Guru belum mengaitkan materi sebelumnya dengan materi yang akan disampaikan.

3. Siswa masih mengerjakan tugas dari pelajaran lain.

4. Siswa belum berani untuk menjawab pertanyaan dari temannya.

5. Guru kurang mengefisiensikan alokasi waktu dalam kegiatan pembelajaran.

6. Siswa belum tertib dan tenang saat siswa menyampaikan hasil diskusi di depan kelas.

Adapun rencana perbaikan yang akan dilaksanakan pada siklus II ini, yaitu:

1. Guru menyampaikan manfaat mempelajari materi yang akan dibahas dalam kegiatan pembelajaran, mengaitkan materi sebelumnya dengan materi yang akan dibahas, dan menyampaikan tujuan pembelajaran, serta mengecek kehadiran siswa.

2. Guru lebih mengarahkan dan membimbing siswa untuk saling membantu dan bertanya kepada anggota kelompok yang lebih mampu.

3. Guru memberikan kesempatan serta lebih memotivasi/mendorong siswa agar berani bertanya apabila belum jelas/sependapat. Misalnya, dengan memberikan pujian, serta tepuk tangan kepada siswa yang berani mengemukakan pendapatnya.

4. Guru lebih mengefisiensikan alokasi waktu pembelajaran sehingga setiap kegiatan pembelajaran dapat terlaksana.

5. Guru memberikan peringatan yang tegas kepada siswa/anggota kelompok yang tidak serius dalam berdiskusi atau tidak serius dalam memberikan pertanyaan/jawaban terkait dengan materi yang disampaikan.

6. Guru lebih tegas dalam mengatur jalannya kegiatan presentasi saat siswa menyajikan hasil diskusi di depan kelas, sehingga siswa lebih tertib dan tenang.

\section{Siklus II}

Pada siklus II peneliti melaksanakan kegiatan belajar mengajar yaitu 1 kali pertemuan. Pertemuan siklus II pada tanggal 22 Juni 2018 dengan alokasi waktu $3 \times 35$ menit. Materi yang dipelajari pada siklus II adalah masih sama dengan siklus I . Untuk evaluasi dilaksanakan pada hari itu juga. setelah mata pelajaran selesai dengan bentuk soal Pilihan Ganda sebanyak 10 soal. Kegiatan pada siklus II terdiri dari 4 tahap:

a. Tahap Perencanaan

Hasil kegiatan pada tahap perencanaan siklus II sama dengan siklus sebelumnya, hanya saja ada perubahan tertentu berdasarkan hasil refleksi yang telah dilakukan pada siklus I. Hal-hal yang perlu disiapkan oleh peneliti pada tahap perencanaan tindakan adalah sebagai berikut:

1. Peneliti berkomunikasi terlebih dahulu mengenai tahap perencanaan yang akan dilaksanakan pada siklus II yang masih mengenai RPP, media dan sebagainya.

2. Guru dan peneliti menetapkan pokok bahasan tentang "Jual Beli "Peneliti membuat RPP dengan metode pembelajaran Sosiodrama, sebelumnya peneliti sudah berkomunikasi terlebih dahulu mengenai RPP dengan metode pembelajaran Sosiodrama sama guru kelas selaku yang memegang mata pelajaran IPS.

3. Peneliti menyiapkan lembar kerja siswa/LKS yang berupa soal Pilihan Ganda. Peneliti juga mempersiapakan lembar observasi aktivitas 
guru dan siswa selama proses pembelajaran yang telah dibuat.

4. Peneliti juga menyiapkan alat mengajar yaitu seperti:, Buah-buahan, beras, sayur, tas, dan buku.

\section{b. Tahap Pelaksanaan Tindakan}

\section{Siklus II}

1. Kegiatan Awal

Pada siklus II guru kembali mengecek kehadiran dan kesiapan siswa dalam belajar, serta menjelaskan kembali dengan rinci langkahlangkah metode pembelajaran Sosiodrama dalam mengerjakan soal LKS. Kemudian guru mengingatkan siswa tentang materi yang telah dibahas pada siklus I dengan memberikan apersepsi dan mengajukan pertanyaan, "anakanak siapa yang masih mengingat apa yang dimaksud dengan Jual Beli?". Selanjutnya guru kembali menyampaikan manfaat dan tujuan pembelajaran yang ingin dicapai siswa yaitu menyelesaikan masalah yang berkaitan dengan materi yang akan dibahas. Pada kegiatan awal, siswa yang tidak serius dalam belajar sudah bisa diatasi oleh guru, keadaan kelas kembali nampak tenang saat pembelajaran berlangsung. Ketika guru mengajukan pertanyaan dengan mengingatkan materi pada pertemuan sebelumnya, antausias siswa ditandai dengan munculnya keberanian mereka mengacungkan tangan untuk menjawab pertanyaan dari guru.

\section{Kegiatan Inti}

Pada siklus II, langkah-langkah pembelajaran yang dilakukan guru yaitu guru meminta siswa untuk memparaktikkan metode sosiodramsa tentang kegatan jual beli,yaitu seperti: 1) Ada sebagai penjual di warung; 2) Ada sebagia penjual di pasar; 3) Ada sebagai penjual di supermarket; 4) ada sebagai tukang Ojek ketiaka dan 5) ada juga sebagai pembeli, mereka sangat antusias dalam mengerjakan peran mereka masing-masing. Kemudian guru kembali melakukan tanya jawab dan menunjuk beberapa siswa untuk menemukan manfaat dari setiap mereka perankan. Semua siswa tampak bersemangat ingin memberikan jawaban/pendapatnya.

Guru kemudian membagikan LKS untuk didiskusikan setiap kelompok, dan menjelaskan kembali tata cara mengerjakan LKS. Siswa terlihat sudah memahami langkah-langkah pengerjaan LKS. Dalam kegiatan diskusi, guru memberikan bimbingan pada siswa baik individu maupun kelompok dan selalu mengingatkan siswa untuk saling membantu serta saling memahami dalam mengerjakan LKS kelompok. Dalam kegiatan diskusi, siswa tampak saling membantu anggota kelompoknya dalam mengerjakan tugas untuk mendapatkan hasil yang terbaik. Siswa juga lebih bersemangat dengan motivasi yang selalu diingatkan oleh guru yaitu memberikan penghargaan berupa hadiah serta memberikan nilai tambah bagi kelompok yang hasil kerjanya baik.

Setelah semua siswa selesai mengerjakan LKS, guru kembali menugaskan siswa untuk membahas hasil Evaluasi di depan. Dalam kegiatan presentasi kelas, siswa semakin menunjukkan keberaniannya dalam mengajukan pertanyaan/memberikan jawaban. Serta semangat mereka saat mengajukan pertanyaan/memberikan jawaban yang berbeda kepada siwa penyaji.Guru hanya menambahkan beberapa jawaban/komentar kepada anggota penyaji yang tidak bisa menjawab. Dalam kegiatan diskusi, siswa tampak sangat aktif dan suasana kelas semakin tertib dan tenang.

\section{Kegiatan Akhir}

Pada siklus II, kegiatan yang dilakukan guru melakukan tanya-jawab dengan siswa untuk menarik kesimpulan dari materi yang telah dipelajari, menanyakan kembali materi yang belum dipahami siswa, dan memberikan penguatan kepada siswa. Siswa ada yang mengajukan pertanyaan terkait dengan materi yang telah disampaikan oleh guru. Guru juga membimbing siswa dalam membuat kesimpulan dengan memperbaiki/menambahkan jawaban temannya. Siswa sudah nampak aktif dalam membuat dan menambahkan kesimpulan.

Pada siklus II, siswa semakin menunjukkan semangat untuk mengerjakan Soal yang diberikan dan keberaniannya dalam menjawab/mengajukan pertanyaan dibandingkan pada siklus sebelumnya. Hal ini dikarenakan siswa termotivasi oleh penghargaan yang diberikan oleh guru berupa hadiah dan nilai tambah bagi siswa yang hasil kerjanya baik. Dalam mengerjakan LKS, siswa nampak lebih tenang dan waktu bisa terpakai dengan baik, dikarenakan guru melakukan pengontrolan dan bimbingan secara kontinu kepada semua kelompok.

c. Tahap Observasi dan Evaluasi

1. Hasil observasi aktivitas mengajar guru

Pada proses pembelajaran di kelas, guru melakukan aktivitas mengajar sesuai dengan rencana pelaksanaan pembelajaran siklus II. Aktivitas guru selama proses pembelajaran berlangsung diamati oleh observer yaitu guru kelas III dan. Hasil observasi terhadap aktivitas guru terdiri dari beberapa indikator yang diamati 
oleh observer selama pembelajaran berlangsung sama dengan siklus I. Aktivitas guru pada siklus II terjadi peningkatan dari siklus I, dari jumlah skor yang diperoleh guru pada siklus II lebih tinggi dari siklus I.

Berdasarkan lembar observasi aktivitas guru pada siklus II terlihat bahwa aktivitas guru berkategori sangat baik, hal ini sesuai dengan pedoman kriteria aktivitas guru berdasarkan interval. Kekurangan pada pembelajaran siklus II yaitu guru tidak mengaitkan materi pelajaran yang akan dibahas dengan materi sebelumnya atau dengan kehidupan nyata dan guru tidak menugaskan siswa untuk kembali mempelajari materi yang telah diberikan.

2. Hasil observasi aktivitas belajar siswa

Data aktivitas siswa selama kegiatan pembelajaran berlangsung diperoleh dengan menggunakan lembar observasi. Aktivitas belajar siswa yang dilakukan oleh observer terjadi peningkatan pada siklus II. Berdasarkan lembar observasi aktivitas siswa pada siklus II terlihat bahwa aktivitas siswa berkategori sangat aktif, hal ini sesuai dengan pedoman kriteria aktivitas siswa berdasarkan interval. Kekurangan dalam proses pembelajaran siklus II yaitu siswa masih enggan untuk menjawab/menanggapi pertanyaan yang diajukan kelompok lain, dan masih kurangnya partisipasi siswa dalam memperbaiki/menambahkan kesimpulan yang diberikan oleh temannya.

3. Hasil evaluasi siswa

Setelah proses pembelajaran, guru melakukan evaluasi untuk melihat sejauh mana siswa menyerap materi yang sudah diajarkan di kelas. Evaluasi siklus II dilaksanakan pada akhir pembelajaran dengan memberikan soal dalam bentuk pilihan ganda sebanyak 10 soal.

Jadi hasil evaluasi belajar siswa siklus II dalam pembelajaran IPS dengan menggunakan metode sosiodrama, nampak siswa yang mengikuti tes 15 orang, dengan nilai tertinggi 90 dan nilai terendah 70. Sedangkan jumlah tes yaitu 10 dengan rata - rata kelas 82,7. Presentase ketuntasan klasikal yaitu 93\% dengan jumlah siswa yang tuntas sebanyak 13 orang dan jumlah siswa yang tidak tuntas sebanyak 1 orang. Salah satu penyebab dari 1 orang siswa yang tidak tuntas adalah siswa tidak serius dalam mengerjakan soal yang diberikan dan kurang memperhatikan penjelasan yang dipaparkan guru.

\section{d. Tahap Refleksi}

Dilihat dari hasil analisis observasi aktivitas mengajar guru, aktivitas belajar siswa, dan hasil evaluasi belajar siswa pada setiap siklus, terjadi peningkatan skor pada setiap siklus yang telah dilakukan. Dengan demikian indikator yang ingin dicapai oleh peneliti sudah sesuai dengan harapan.

\section{SIMPULAN DAN SARAN}

\section{A. Simpulan}

Berdasarkan hasil penelitian yang sudah dilakukan dengan menggunakan metode sosiodrama dapat meningkatkan motivasi belajar siswa pada materi pokok jual beli kelas III di MI Raudlatusshibyan NW Belencong Kecamatan Gunungsari Kabupaten Lombok Barat Tahun Ajaran 2017/2018. Selain itu, penerapan metode sosiodrama juga dapat menjadikan siswa lebih serius dalam mengikuti pembelajaran karna walaupun pembelajaran dilakukan secara kelompok atau klasikal tetapi harus dapat diindividualisasikan dengan melihat nilai yang di peroleh oleh tiap-tiap individu siswa.

\section{B. Saran}

Berdasarkan pada penelitian yang telah dilaksanakan, peneliti menyampaikan beberapa saran agar menjadi bahan pertimbangan, antara lain:

Bagi Guru: pertama, Hendaknya tidak menggunakan satu buah buku paket dalam proses belajar mengajar. Hal ini dilakukan agar siswa memiliki wawasan yang cukup luas dalam memahami pelajaran. Kedua, Guru sebaiknya mengkondisikan kelas dengan baik ketika proses pembelajaran berlangsung agar siswa lebih focus belajar dan tidak melakukan kegiatan lain.

Bagi Siswa: pertama, Siswa sebaiknya memperhatikan guru saat kegiatan pembelajaran sudah dimulai. Kedua Siswa sebaiknya lebih antusias dalam mengikuti pembelajaran sehingga pembelajaran dapat menjadi lebih menyenangkan. Ketig, Siswa sebaiknya bisa mengerjakan soal dengan mandiri dan tenang saat evaluasi pembelajaran dilakukan.

\section{DAFTAR RUJUKAN}

Ahmadi, Rulam. 2016. Pengantar Pendidikan Asas dan Filsafat Pendidikan. Yogyakarta. Ar-Ruzz Media.

Aqib, Zainal. 2015. Model-Model,Media, dan Strategi Pembelajaran Kontekstual Inovatif. Bandung. Yrama Widya.

Aqib, Zainal. 2010. Penelitian Tindakan Kelas (PTK) Untuk Guru SD,SLB,TK. Bandung. CV Yrama Widya.

Mappanyompa. (2019). Problematika Pengkaderan Di Perguruan Tinggi Muhammadiyah 
Mataram Dalam Perspektif Norma

Pengkaderan Muhammadiyah, Media

Keadilan: Jurnal Ilmu Hukum, 10 (1), 82-98

Fudyartanta, Ki. 2011. Psikologi Umum.

Yogyakarta. Pustaka Pelajar.

Hernawan, Asep Herry. 2010. Perkembangan

Kurikulum dan Pembelajaran. Jakarta Universitas Terbuka.

Isjoni. 2010. Cooperative Lerning Efektifitas Pembelajaran Kelompok. Bandung. Alfabeta.

Purwanto, Ngalim. 2018. Prinsip-Prinsip dan Teknik Evaluasi Pengajaran. Bangung. Remaja Rosdakarya.

Suwarno. 2011. Pengantar Umum Pendidikan. Jakarta. Aksara Baru.

Sumantri, Musyani. 2010. Perkembangan Peserta Didik. Jakarta. Universitas Terbuka.

Supardi. 2011. Bacaan Cerdas Menyusun Skripsi. Yogyakarta. Kurnia Kalam Semesta

Syah, Muhibbin. 2014. Psikologi Pendidikan. Bandung. PT Remaja Rosdakarya.

Trianto. 2013. Mendesain Model Pembelajaran Inovatif-Progresif. Jakarta. Kencana.

Taniredja, Tukiran dan Harmianto, Sri. 2015. Model - model Pembelajaran Inovatif dan Efektif. Bandung. Alfabeta.

Wahab, H.A. Aziz. 2015. Pendidikan Pancasila dan Kewarganegaraan. Jakarta. Universitas Terbuka.

Mappanyompa. (2019). Pengaruh Pendidikan Kemuhammadiyahan Terhadap Sikap Perilaku Siswa, Ibtida'iy Journal PGMI, 4 (1),17-29.

Wardhani, Igak. 2018. Penelitian Tindakan Kelas modul 1. Jakarta. Universitas Terbuka.

Winataputra, Udin. 2010. Materi dan Pembelajaran Pkn SD. Jakarta. Universitas Terbuka.

Sugiyono. 2012. Metode Penelitian Kuantitatif Kualitatif. Bandung. Alfabeta.

Sanjaya,Wina. 2013. Penelitian Pendidikan Jenis Metode Dan Prosedur. Jakarta. Kencana.

http://www.wawasanpendidikan.com/2016/01/K

elebihan-serta-Kekurangan-Pembelajaran-

Koperatif-Tipe-STAD.html/ (Diakses Pada Tanggal

29, Desember 2017) 